\title{
Inscribing the Egalitarian Event: Jacques Rancière and the Politics of Iterability
}

The question of how we assess the impact of democratic events has resurged in its all complexity since the mass demonstrations and political uprisings of $2011 .^{1}$ The hope generated by the image of ordinary people acting together to create extraordinary circumstances frequently morphs into disappointment as the event's radical character gets measured against its often seemingly conservative, indiscernible or even sometimes oppressive outcomes, as normality returns and participants resume their place in society. Simple before and after analyses, while demanding that events quickly engender radical change, end up sceptical towards them, contrasting the equality enacted by the participants with the inequality continuing in its wake. However, to interpret events merely in terms of their immediate and measurable results, to assess whether they achieve their apparent objectives, overlooks how they can only resonate beyond the moment of their irruption if their impact exceeds precise measurement and objectification, remains a site of interrogation and contestation, if they reveal the possibility of alternative worlds without imposing one world as the only possible alternative.

Jacques Rancière's work reads events to affirm their non-closure, their resistance to calculation or discursive control by the regimes they disrupt in order to highlight their potential for reinscription across time and space. Occurrences become events, he argues, when individuals form a collective subject, acting beyond their designated social position to prove their equality with the powerful, when they inscribe in society the power of anyone and everyone to interrupt social routines in order to reclaim time and space for political action in a context which suppresses politics. This demonstration of the democracy that no regime can institute or eradicate confronts 'every legitimisation' of the social order with 'its ultimate lack of legitimacy' to expose the potential for further events that challenge social givens. ${ }^{2}$ My assertion that Rancière examines how the equality performed by events can be permanently 
reinscribed counters much secondary literature on his work. That events stage the anarchy that ruptures but never replaces social orders has led some critics to reproach him for reducing politics to fleeting interruptions without lasting institutional impact. ${ }^{3}$ In response, I shall argue that Rancière's work illustrates how events supplement democratic institutions, often produced or shaped through earlier events, to test their egalitarian principles against reality by realising them in action. ${ }^{4}$ As supplements, they are both additional to institutions and also necessary for their actualisation, inscribe themselves on them and are already inscribed within them. ${ }^{5}$ This ambiguity makes it harder for authorities to dismiss democratic action without contradicting the principles they allegedly uphold.

As Rancière insists, Democracy, which he interprets as the right to rule of anyone and everyone, is not assured by 'the universality of the law' because 'that universality is ceaselessly privatised by the logic of governments', either explicitly by denying rights to parts of the population or implicitly, which is the case of modern western societies, by restricting 'the sphere of citizenship to a definite set of institutions, problems, agents and procedures.' To assure it, the law has to be supplemented by the constant emergence of subjects who 'stymie' this 'privatisation of public life' by inscribing within it issues, cases or situations thought not to belong there by the powerful. ${ }^{6}$ So if events, as Rancière suggests, rupture the basis of power in society by demonstrating the right to rule of those deprived of that right, their impact is not simply determined by how institutions re-mark them but also by how they (re)mark institutions as objects of public dispute open to questioning by all. In this sense, institutions, rather than accounting for events, should be repeatedly held accountable for them, so that the evental moment is 'not a vanishing point in the flow of time' but 'a momentum, a shift in balance, and the establishment of a new flow'?

How is the momentum maintained without requiring policing to ensure its maintenance? How does the shift of balance become effective without establishing another hierarchy? His 
discussion of 'the ever-to-be-re-commenced invention of the community of equals' helps answer these questions, examining how equality can be (re)inscribed socially through what I call egalitarian iterations. ${ }^{8}$ Egalitarian iterations occur when subjects test the equality inscribed by earlier events by re-enacting it in diverse sites and situations both to defend that inscription and demonstrate its potential for reinscription in unanticipated ways. ${ }^{9}$ Iterations enable subjects, I argue, to occupy the interval between abstract universal equality and their inequality as concrete, historically situated individuals, to reveal the world where they count as equal within the one where they do not. ${ }^{10}$ As demonstrations of equality are made to and against police orders, their effects always get inscribed, Rancière asserts, in 'hybrid forms' which 'may well be described as conquests' for the oppressed or 'as new means of tightening the bonds of domination, or as aspects of the consensual self-regulation of a social machine. ${ }^{11}$ However, to reduce events to 'such profit-and-loss calculations' reabsorbs them within the dominant discourse which seeks to account for them without remainder. What becomes imperative, for Rancière, is to perceive the universal within the particular conflict which triggers the event so that that conflict is not confined to the defence of a set local interests but is seen as an iteration of the anarchic equality that unsettles all regimes of power. In this way, the event demonstrates to others their own capacity to contest those regimes by living differently from what they prescribe. Rancière's dissensual reading of events therefore affirms how their hybrid inscriptions leave their accounts unsettled, creating the possibility for re-accounting, for 'a fresh corroborative delineation of the community of equals.' 12

The egalitarian community, emerging 'in the junction between the violence of a new beginning and the invocation of something already said, already inscribed', never becomes an institution, acting as the presupposition which the unequal retrospectively prove by already living equally in hierarchical contexts. ${ }^{13}$ Its fleeting occurrence does not mean that it simply vanishes in time but rather that its verification of equality remains 'forever in need of 
reiteration' ${ }^{14}$ Its emergence combines the singular event of the 'forced entry' of new subjects into societies with 'the ongoing creation of equality'. ${ }^{15}$ So while acts of equality are singular, being performed in a particular time and space by subjects who are constituted through that performance, they also need to be recognised as part of the continual process of creating equality. Each performance can therefore be understood as a unique event and also a repetition of the egalitarian presupposition.

To explain this tension between event and repetition, newness and continuity, I shall draw on Derrida's concept of iterability which indicates how the event's originality makes a mark only by being inscribed within a pre-existing signifying system which both preserves that originality by allowing others to re-mark it but also disrupts it by representing it in pre-given terms. ${ }^{16}$ Iterability combines the latin iter (again) with the Sanskrit itara (other) and describes how the production of meaning entails an undecidable relation between repetition and alteration. Words can be recognised and used by a community of speakers only if they are repeatable across time and space. Each repetition of a word occurs in a new context which alters its meaning. So any repetition is always characterised by a degree of originality, however slight, and alteration. Equally, there is no standalone signifying event. While an event worthy of its name must be, for Derrida, singular, irruptive and unpredictable, its unique occurrence manifests itself only on the condition of a possible re-marking. That is, the event cannot initially make a mark without also being re-markable or iterable. So iterability highlights how even a one-off event requires repetition and alteration for its social existence. This constitutive repeatability and alterability thwarts attempts to limit the event's effects spatially and temporally. It illuminates, I shall argue, how later events potentially build solidarity with contemporaneous or previous ones by borrowing and also recontextualising their egalitarian words or actions to re-assert or expand their meaning. ${ }^{17}$ 
My article has two main sections. First, I address the frequent criticism that Rancière's work privileges the disruption of events over their social inscription. If events, as Rancière suggest, repartition who is seen and heard politically, they cannot simply disrupt social orders but must also make a mark on them. The disruption, I maintain, takes the form of an inscription so that the equality enacted can be re-marked by the subjects themselves and their community. This inscription, precisely because it disrupts the perceptible, remains a site for inquiry. I then argue that Rancière considers the momentum created by emancipatory moments more than his critics concede. I examine three events which restage earlier events to test and defend their egalitarian inscription: that of Olympe de Gouges whose reiteration of the Declaration of the Rights of Man and Citizen of 1789 shows how equality can be demonstrated by those considered neither man nor citizen; the tailors' strike of 1833 which proves the universal equality declared by the 1789 and 1830 revolutions by inscribing it within the hierarchical space of the workshop and the French students' strike of 1986 which defends the democratisation of the university promoted by the events of May 68 against privatising measures. While these events represent the difference between the explicit (the denial of rights) to the implicit (the restriction of the sphere of citizenship) privatisation of public life, they share common practices. Their actors presuppose the community they invent by already exercising the rights they struggle to obtain or re-assert. ${ }^{18}$ This non-linear temporality undermines the chronology positing first the event and then its inscription: the event involves living as if equality has already been inscribed. They do not therefore so much demand equality with their societies as prove they are already equal and therefore to treat them otherwise would contradict all evidence.

To emphasise the iterative dimension of Rancière's politics underlines how seemingly fleeting events remain forever re-markable by subjects who can reiterate their words and actions to retrace their sites of struggle, to forge solidarity with them, as they (re)inscribe an 
ongoing collective effort to expand and protect the public sphere against the privatising force of governments. For if democracy, 'as the government of anybody and everyone', generates 'hatred' among the powerful who represent it as an obstacle to efficiency and profitability, then it becomes imperative to challenge that representation through the regular re-marking of the people's power to decide what counts politically. ${ }^{19}$

\section{Political Impurity}

My insistence that Rancière explores the momentum of events questions the frequent criticism that his work privileges disruption over inscription. ${ }^{20}$ The 'one off' character of 'acts of equality', for Rancière, seemingly supports such criticism. ${ }^{21}$ If those acts seek to found an order, they reproduce the inequality they aim to challenge: to institute and maintain that order would require a hierarchical division between those that order and those that are ordered. For Rancière, the impossibility of an egalitarian state does not underline, however, the limited potential of politics understood as the demonstration and declaration of equality by subordinates, but rather its ongoing possibility. Politics, without its own sphere of enactment or objects, operates in and on societies or what Rancière calls police orders by inscribing within them those that they previously did not count. ${ }^{22}$ These 'inscriptions that account for the unaccounted' may interrupt those orders but without them there would be no need for the inscription in the first place. ${ }^{23}$ 'Political impurity' deconstructs any simple opposition between disruption and inscription, event and repetition. ${ }^{24}$ The police organises society so that people occupy positions or play roles according to its estimation of their capacity. Its essence lies not exclusively in repressing or controlling but in a specific distribution of the sensible (le partage du sensible). The distribution of the sensible informs our sensory experience of the relation between the parts and the whole of the community, deciding who is seen and heard. The French verb partager means both sharing and partitioning. So le partage du sensible enables certain groups or individuals to participate by 
excluding others. The police distribution denies this double sense, claiming to count everyone to the exclusion of any void or supplement. ${ }^{25}$

So politics intervenes in and reconfigures police orders when the part without part stages a dispute over how the community is organised by deciding to partake in its organisation despite allegedly having no part. Disputes serve two functions, both unsettling police communities by making visible those they exclude and also creating the community where the excluded have a say. 'Politics, before all else, is an intervention in the visible and the sayable'. ${ }^{26}$ Its aesthetic dimension underlines the inseparability of rupture and inscription. For the break to be perceived, it has to be traced through by the sensory regime that it ruptures so that its difference becomes perceptible. Politics happens through dissensus as the revelation of 'the contradiction of two worlds in a single world': the world where the part without part partakes and the one where it does not. ${ }^{27}$ The single world appears only if the event of the community of equals inscribes itself within the exclusionary community, if the division enabling sharing becomes visible. The egalitarian community does not therefore form an alternative to the police but supplements it with an alternative (ac)count of the parts and the whole, by causing the logics of equality and inequality, politics and police to meet without reconciling them. ${ }^{28}$ Reconciliation would produce an entire society of equals, which, were it possible, would, like the police, aim to count everyone without remainder, thereby becoming its opposite, denying any room for dissensus.

The community of equals therefore never becomes a state, remaining 'a supposition to be posited from the outset' because, without it, the unequal would never experience the wrong of their domination and feel compelled to challenge it, and 'to be constantly reposited' because it remains 'tied to the act of its own verification, which is forever in need of reiteration.' ${ }^{29}$ Any demonstration of the egalitarian supposition is necessarily addressed to others and therefore has to be iterable. Iterability both constitutes and divides the event. On the one 
hand, it allows the uncounted themselves and others to take account of the equality they have enacted. On the other, that accounting process exposes their actions to being (re)interpreted in ways which potentially augment or diminish their significance. This uncertainty means that 'equality is not a given' ${ }^{30}$ but a force whose 'actual effects need to be verified.' ${ }^{31}$ That verification becomes socially effective only when it obliges the police community to perceive a shared community with those they have marginalised. But that perception, as we shall see, does not have to endorse the event to ensure its social inscription. To dispute the existence of a shared community ends up confirming its existence as a disputable object.

As events produce dissensus, their effects can never be fully agreed upon. They are permanently to be verified through iterations which simultaneously repeat and alter them. Rancière's analysis of the Aventine Secession of 494 BCE, first told by Livy writing a hundred years later and then retold by Pierre-Simon Ballanche in 1830, illustrates this tension, showing how the police's attempt to justify Rome's hierarchy to deny the plebeians' assertion of self-rule eventually concedes the equality it refutes. ${ }^{32} \mathrm{We}$ shall consider this event for two reasons: 1) it demonstrates the iterability involved in proving equality in an unequal context and in the event's reception through time; 2) on a related point, it offers a way of reading an event that underlines its resistance to discursive control by political elites.

\section{The Aventine Secession and the Politics of Iterability}

The plebeians withdraw from Rome to protest against Appius Claudius' oppressive rule. In response, the Roman patricians send the emissary Menenius Agrippa to deliver an apologia to convince them of the necessity of inequality. His apologia, composed as a fable, likens Rome to a human body where its members (the hands, eyes, ears, feet and tongue) revolt against the stomach which, they believe, lives parasitically off their labour. The members eventually realise that they cannot function without the stomach and return to work. The plebeians listen 
but refuse to yield, acting as the patricians' equals by requesting a treaty with them. Their request shows their ability to see through the literal content of Menenius' discourse which rationalises Rome's hierarchy to the equality which the act of addressing them assumes:

Menenius Agrippa explains to the plebs that they are the stupid members of a city whose soul is its patricians. But to teach the plebs this way, he must assume they understand what he is saying. He must assume the equality of speaking beings, which contradicts the police distribution of bodies who are put in their place and assigned their roles. ${ }^{33}$

Rancière, while criticised for not analysing how authorities respond to events ${ }^{34}$, illustrates in this central example how the patricians' dismissive response, which seeks to re-assert their authority, eventually performs its own lack of authoritative control. Menenius' speech undermines itself by staging a community which contradicts the one it describes, for to persuade the plebeians of their worthlessness already treats them as worthy of persuasion, as equal speaking beings.

To initiate this dialogue between equals, the plebeians 'execut[e] a series of speech acts which mimic those of the patricians: they pronounce imprecations and apotheoses; they delegate one of their number to go and consult their oracles; they give themselves representatives [...] Through transgression, they find that they too, just like speaking beings, are endowed with speech that does not simply express want, suffering, or rage, but intelligence'. ${ }^{35}$ By transgressively repeating their masters' actions and words, they challenge their mastery, forcing entry into the community of speaking beings. Iteration, with its play of continuity and newness, redistributes the sensible, rendering their equality perceptible to themselves and the patricians who have denied it, presuming the world it seeks to invent. The emergence of that world has already affected the patricians' world by making it account for its inequality before those that supposedly do not count. 
So equality is both stated and produced by the plebeians' actions. This mutual contamination of the constative and the performative is essential for proving the wrong of inequality. The plebeians verify their equality only if they already take it for granted: to dispute their subordination, they already have to experience it as unjust. Yet, the act of verification makes sense only in a context where equality cannot be taken for granted. So it creates the equality whose existence it proves, inscribing it socially so that the unequal can retrospectively show to themselves and their superiors that they were never truly unequal and should not have been treated as such. The complex temporality which projects the equality demonstrated and declared to a point before the demonstrative and declarative act refuses any simple chronology plotting first the event and then its inscription. Egalitarian struggles project the future into the past, exercising the right to participate socially before that right is recognised. So events are grasped only as inscriptions, consisting less in the pure invention of equality than its discernment as a 'mere assumption' 'within the practices implementing it. ${ }^{36}$ The literarity or excess of meaning Menenius' apologia, which allows the plebeians to read the concession of equality in its rationalisation of inequality, also subjects their own speech acts to reinterpretation in ways which render uncertain their underlying intentions. The disagreement between Livy and Ballanche over the event's significance highlights how reiteration never simply repeats facts but constitutes and redefines them. Ballanche exposes the limits of Livy's account of it as an angry revolt with his 'story-apologia' which performs 'a restaging of the conflict in which the entire issue at stake involves finding out whether there exists a common stage where plebeians and patricians can debate anything' ${ }^{37}$ Their disagreement highlights the uncertain and therefore contestable character of the event's inscription, how its verification of equality needs constant reiteration. To restore order, the police attempts to diminish events, pretending that "there is nothing to see and so nothing to do but move along': that attempt would be unnecessary if events, for Rancière, reduced 
simply to passing interruptions. ${ }^{38}$ Rancière's repetition of the Livy-Ballanche disagreement re-opens the dispute about what happened in $494 \mathrm{BCE}$, staging a dissensus of two readings of one event: an egalitarian and non-egalitarian reading. It resists the police drive for closure, showing how the event's iterability constitutes and destabilises its meaning, enabling both its depoliticisation if it gets dismissed by the powerful and its subsequent repoliticisation as its dismissal gets contested. To dismiss the event judges it significant enough to be dismissed, thereby generating an excess of meaning to dispute.

Politics $[\ldots]$ consists of the efforts to enlarge the space of dissensus by struggling against a machinery of interpretation that endlessly either erases the singularity of circumstances or reabsorbs it into categories of domination, transforming those who have protested back into representatives of backward populations, egotistical entities, or restricted minorities. ${ }^{39}$

Inscribing the alternative worlds revealed by events within a context that suppresses alternatives will entail constantly resisting their recodification and reabsorption by the dominant discourse. Subjects have first to make the authorities perceive and respond to that world before any battles over its interpretation can occur. As Rancière's discussion of the Aventine secession shows, even if the authorities deny its existence, that denial does not necessarily spell failure: it also re-marks its entry into the public sphere as an issue that the authorities have been forced to take account of. Destabilising the police's monopoly over the visible and audible does not automatically involve, Rancière insists, establishing a counter monopoly. Rather it involves turning the event into 'a site for inquiry in which anyone can speak' provided that speakers accept their words and actions will also be susceptible to questioning. This allows the event to reverberate as its meaning remains an object of disputes which continue 'to challenge the obviousness of the given world' ${ }^{40}$ Rancière's insistence that 'logos is never simply speech but it is always indissolubly the account made of this speech' affirms this excess of meaning which fuels politics. ${ }^{41}$ Aristotle's distinction between 
phone or voice, as the emission of pleasure or pain, and logos or speech, as the capacity to differentiate the just from the unjust, forms the object of political dispute and therefore cannot precede and found politics, as Aristotle maintains. Individuals do not possess logos: others have to be forced to perceive it in the sounds they make. Logos, as simultaneously speech and account, reinforces the idea that the event of declaring equality is inseparable, for Rancière, from its inscription: it is constituted retrospectively through the accounts made of it, through 'a never ending settling of accounts'. ${ }^{42}$

\section{The Afterlife of Events: Egalitarian (Re)iterations}

Rancière's discussion of the 1789 Declaration of the Rights of Man and Citizen illustrates the inseparability of the event from its constant (re)inscription through the continual struggles for rights. It explores how individuals fuel the momentum of the emancipatory moment through the practice of egalitarian iterations whereby they verify the power of the legal inscription of universal equality and freedom by (re)enacting it in particular situations or places to demonstrate both the wrong of their exclusion and their right to perform their own inclusion. They are egalitarian in that they are made in the name of anyone and everyone rather than in name of a specific group or identity and in that they also expose the excess of meaning in laws, policies or discourses which destabilises any claims to complete authority over their interpretation, thereby opening them to reinterpretation by those without authority.

Rancière's thought therefore explores, I argue, how events get re-activated, how their impact gets inscribed in new areas of social life and also in the everyday more than his critics concede. My analysis will flesh out Chamber's idea of 'a politics of the police'. As we will always live in police orders, Chambers asserts, 'we must remain committed to and concerned with "a politics of the police" in the sense of changing, transforming and improving' them. It necessitates 'democratic vigilance.' ${ }^{43}$ Rancière's assertion that there are 'worse' and 'better' 
police societies supports Chambers' reading. He says little about what 'a better one' entails other than it does not 'adhere to the supposedly natural order of society or the science of legislators', having been 'jolted out of its natural logic' by 'all the breaking and entering of the egalitarian logic'. ${ }^{44}$ Egalitarian iterations jolt police orders, refusing submission to 'the science of legislators' as non-experts interpret the words of legal or political texts and apply them to their daily lives to challenge or exceed legislators' intentions. This practice does not simply oppose police institutions but acts upon them to regulate, redirect or reinterpret them as subjects live as if those institutions already offered what their action demands of them. It performs the democratic vigilance which Chambers' politics of the police advocates, measuring the distance between the equality legally inscribed and the fact of inequality, not to demystify the law as an ideological screen for domination but to impose an obligation to proceed from its abstract written form to its deployment in reality. If there are better and worse police orders, a politics of the police would not merely transform or improve them, but also promote their better aspects, 'defend the solidarity and redistribution won by social struggles' against non-egalitarian policies or laws, against total control from political elites. ${ }^{45}$ Rancière's historical examples exemplify, I argue, how events supplement institutions by actualising their principles.

The iterability constitutive of events leaves them susceptible to repetition, alteration and translation into the ordinary as individuals attest their occurrence, making them count as an origin through social practices. It preserves the event's originality while simultaneously disturbing it. It becomes recognisable to the interrupted context only if it gets repeated in preexistent terms whose meaning can never be fixed. As equality gets enacted to prove its existence, any declaration of equality is itself a reinscription of its enactment. So the Declaration of the Rights of Man and Citizens of 1789 is 'rooted in nothing more than in the logic of repetition'. It 'repeated the event that had already taken place, constituting it as 
already written, already obligatory. It was itself designed for repetition, and to further whatever repetition was capable of producing by way of new egalitarian events'. ${ }^{46}$ The Declaration reiterated the event which had verified its statement of equality and freedom avant la lettre and which had also inaugurated the world in which such a statement could take effect. Its inscription of the event was an event itself as it legally enshrined the revolutionaries' particular actions as a permanent mark of universal freedom and equality. To declare the rights of man and citizens, the revolutionaries had to act as if those rights had already been declared, they had to rule themselves without any right to do so. However, if they were already bearers of rights, their declaration would be unnecessary. The declarative act inscribes both the presence and absence of equality in the social field, affirming the need for its constant verification. Repetitions of the Declaration at once expose the limits of its universality (it needs to be repeated most urgently when rights are violated) and also confirm its originating power, its potential to engender new disputes over rights yet to exist officially but which subjects nonetheless have already exercised.

This retroactivity applies therefore not just to the moment of the Declaration's institution but to the ongoing politics of human rights. The force of its legal inscription is verified after the event of exercising the rights it seeks to guarantee. It remains forever unclear whether the Declaration states or produces freedom and equality. This combination of the constative and performative generates and defines struggles for rights. Those struggles occur when rights have been denied and therefore need bringing into existence through their enactment. However, that denial can be experienced only if those rights are thought already to exist. Human rights are simultaneously presupposed as well as performed each time they are exercised. For example, Olympe de Gouges famously reiterates the Declaration with her Rights of Women and Female Citizens to contest women's relegation to the domestic sphere. Published on 14 September 1791, the same day as the constitution is ratified, her text seeks to 
intervene in the debates raging over the specifics of the constitution. It does not so much seek constitutional legitimation for women's equality as prove that it is already legally inscribed in the constitutional principles of universal equality and freedom and therefore cannot be legitimately excluded from the constitution. It repeats, using the subject 'citoyenne' and 'woman', many of the clauses of the 1789 Declaration, which guided the drafting of the constitution, to disrupt the link between man and Man, man and citizen presumed by the lawmakers. Her iteration therefore confirms that women's equality is already implicit and possible within the revolutionary discourse propagated by those who deem it impossible. Not only does she prove her citizenship discursively but also practically by participating in a public debate from which her sex allegedly bars her. She thus exposes how women are deprived of the rights that they should inevitably have if universal equality is now officially declared and shows through public action that they have the rights denied to them. She becomes a subject, defined by the 'capacity for staging scenes of dissensus', constructing 'the world in which those rights are valid, together with the world in which they are not. ${ }^{47}$

Her iteration causes dissensus by supplementing, Scott indicates, the 1789 Declaration, appearing as both 'superfluous' to it and 'absolutely necessary for its completion.' ${ }^{48}$ This undecidable relation between her Declaration and the Declaration proper means that her text can be read as both inscribing itself upon the original and as already inscribed within it to the extent that dismissing her claims could also mean dismissing those of the constitution. Her article 10 reveals this undecidability, proving how gender equality is already legally accepted: 'Woman has the right to mount the scaffold; she must equally have the right to mount the rostrum' ${ }^{49}$ The universality of the death penalty blurs the distinction between private and public, considering women's lives as politically significant as men's. Therefore, even her execution in 1793 for threatening the revolution by supporting constitutional monarchy does not ultimately defeat her: it could be read as 'spectacularly accomplish[ing] 
[...] her work: to have the state recognise her and treat her as a citizen. ${ }^{50}$ The state takes her words seriously enough to judge them dangerous for public order despite their being uttered by a woman allegedly deprived of public agency. After her execution a warning was issued to republican women not to imitate her in questioning their roles ${ }^{51}$; that warning confirms De Gouges' impact on the public sphere as she is supposedly erased from it, her potential to interpellate other women. To enact equality, subjects have to demonstrate it to others who may refuse that 'evidence and argument' ${ }^{52}$ But the fact of officially refusing it re-marks its encroachment on the public domain, reinscribes it as a site of contestation. By acting as if women's equality is already socially inscribed, De Gouges disturbs the revolutionaries' world more than if she simply demanded its inscription. Such a demand would corroborate their assumption of its inexistence and also their authority to decide who counts. By confirming through discourse and action that the world where women are equal to men is already part of the world where they are considered unequal, it disputes their assumptions.

De Gouges' intervention cannot be judged successful on the grounds that it achieved its stated aims: her proposals were not immediately accepted. However, such a reading would ignore its iterative potential: her Declaration 'inspired feminist challenges to successive governments throughout the nineteenth and the first half of the twentieth century'. ${ }^{53}$ She managed to inscribe the question of women's equality in the public sphere, to generate a big debate about an issue belittled by the authorities. Her inscription of the account of the unaccounted produces 'a space for inquiry' in which anyone can speak, exposing the literarity of the names Man and citizen which leaves them open to being iterated but not embodied by anyone, which raises a 'question or dispute (litige) about who is included in their count' ${ }^{54}$ So rather than seeking to become a master discourse, it exposes what exceeds mastery. It shows how the Rights of Man may be a police institution but it can never be fully appropriated by its logic which always counts communities in terms of their 'empirical parts - actual groups 
defined by differences in birth, by different functions, locations and interests' to the exclusion of any supplement' ${ }^{55}$ Her supplementary text, as both an additional and also necessary part of the constitutional text, as both a repetition and alteration of it, tears 'the fabric of domination' by denying the lawmakers monopoly over the law's meaning, reiterating it to call for not only women's emancipation but emancipation in general. ${ }^{56}$

While a whole society, Rancière insists, cannot be emancipated, democratic events where subjects demonstrate their capacity for self-rule can enhance others' capacity to emancipate themselves, by jolting the natural order of society, by showing its susceptibility to reordering. Emancipation involves subjectification, which forms 'a one that is not a self but the relation of a self to an other'. ${ }^{57}$ The emphasis on relation means that subjectification is not limited to disidentification, as Norval ${ }^{58}$ maintains, but also 'involves an impossible identification, an identification that cannot be embodied by he or she who utters it' ${ }^{59}$ Egalitarian iterations perform this impossible identification, as subjects refuse their police identity by speaking in the name of universal equality not to claim it as their property but rather to show how it belongs to no one and therefore cannot indisputably exclude anyone. These acts of speech divorce 'voice from bodies', reject identity as a specular phenomenon and embrace the 'crossing of identities, relying on a crossing of names: names which link the name of a group or class to no group or no class, a being to a non-being or not-yet-being' ${ }^{60}$ They mediate the universal with the particular so that the category of woman, for example, gets declassified as it becomes identified with the surplus names man and citizen which resist classification. In turn, universality gets contested as its limits are exposed and also affirmed through its reconstitution and expansion to include new positions or areas of social life.

The event does not reduce to the inclusion of pre-given identities or interest groups. If it did, it would simply perpetuate rather than disrupt the police's will to count everyone without remainder. The event, while temporally fleeting, inscribes the potential for its own 
reinscription by making visible the equality that police institutions cannot account for and which therefore require supplementary subjects to do the accounting. Rancière's dissensual politics differs from the liberal democratic tradition which seeks consensus among conflicting interests by attempting to ensure that 'each part of the social body obtains the share it is entitled to' by moulding 'positive laws and rights' 'to fit the diversity of social groups' ${ }^{61}$ For Rancière, to reduce the event to a specific conflict defending the interests of a particular group would restrict its iterative potential. His subjects therefore exceed inclusion or classification in the current order, identifying with the equality that is not identified with anyone in particular. As forms of inscription that (ac)count for the unaccounted, they disrupt 'the identity between law and fact ${ }^{\prime}$ s2 sought by liberal consensus, exposing how egalitarian laws always have to be made accountable by collective action. Rancière thus casts the 'democratic experience' as an 'aesthetic experience', which involves perceiving 'the distance between words and things' not as 'deception' or 'trickery' but as a sign of equality. ${ }^{63}$ That distance gives freedom to speak and act in ways which declassify police classifications, to live the relation between words and things differently from their official meanings.

The gap between law and fact which liberals aim to narrow to promote democratic justice allows, for Rancière, democracy to happen through the innumerable demonstrations of rights by those unequally treated. It provides a site of contestation as the part without part bring the legal inscription of equality to bear on their experience of inequality to dispute that experience as a legal violation. For this reason, Rancière defines the universality of human rights not in terms of any human essence that it allegedly describes but in terms of 'the universality of the arguments to which it gives away'. ${ }^{64}$ The arguments are repeatable by anyone and everyone, across time and space, for the assertion of universal equality makes all particular examples of domination or marginalisation cause for dispute. The arguments take the form of a syllogism, as De Gouges' discourse and, as we shall now see, the tailor's strike 
of 1833 demonstrate. The major premise of tailors' syllogism comes from the preamble of 1830 charter: all French people are equal before the law. The minor premise comes from the workers' experience of inequality which contradicts the major premise. The syllogistic argument allows the tailors to measure the distance between the legal statement and the reality of their daily working lives to impose a rational obligation on the authorities 'to proceed from the declaration of equality to its effective deployment'. ${ }^{65}$ The case of the tailors differs from that of de Gouges: by 1830 workers had proven their right to participate publically. Their strike consolidates that right by expanding the public sphere to their everyday working lives as they verify the revolutionary inscription of free and equal community within the private sphere of the workshop.

\section{Inscribing the Extraordinary in the Ordinary}

The tailors strike because Monsieur Schwartz, the head of the master tailors' association, refuses to listen to their demands for higher wages and better working conditions. That refusal represents unequal treatment, contradicting the Charter's preamble. But the contradictions continue when Schwartz organises a bosses' federation to resist the workers' demands. French law prohibits such federations but only the tailors' federation is prosecuted. The tailors reveal that contradiction by verifying the preamble's egalitarian statement with deeds. They translate their post-revolutionary status as citizens into a new way of striking, which differs from the earlier journeymen's strike whereby workers would protest by damning the town and preventing others from replacing them. Whereas this strike repudiated community, the tailors' strike presumes that they and their employers belong to 'the same sphere of community' inscribed 'in the revolutionary declarations of the equality in law of

man and the citizens'. ${ }^{66}$ It represents them 'not merely as creatures of need, of complaint and protest, but creatures of discourse and reason', able to show the fairness of their pay claims, the irrationality of their adversaries' texts, and their capacity to run their own workshops. ${ }^{67}$ 
Their actions illustrate how events do not occur as isolated moments of disturbance but create the momentum for further events: 'The reasonable arguments of the strikers of 1833 is audible and their demonstration is visible because the events of 1830 , recalling those of 1789 , had torn them from the nether world of inarticulate sounds and ensconced them by a contingent forced entry in the world of meaning and visibility. The repetition of egalitarian words is a repetition of that forced entry'. ${ }^{68}$ The strikers reiterate the preamble to contest and reconfigure the current partitioning of the sensible, by forcing its egalitarian inscription into the workshop currently excluded from the public realm of law whose universality should logically include it. ${ }^{69}$ They exploit the preamble's literarity to demonstrate the law's force by inscribing it in sites outside the law.

Their struggles translate the extraordinary events of 1789 and 1830 into the ordinary to make the private issues of pay and working conditions into public ones. They move from the written inscription of egalitarian community to its performance to oblige their employers to perceive their strike as motivated by reasonable arguments worthy of attention. That performance transforms the local site of the workshop into one of universal struggle, into the fraught meeting point of two opposed sets of relations with two opposed forms of social reality: the reality of the unequal relations of economic dependence is made to confront that of a legal/political relation of equality. This dissensus exposes the division enabling sharing, it proves the existence of a common stage on which they can exchange arguments as equals. That proof requires more than rational argument, involving a poetic dimension which inaugurates 'the world where argument can be received and have an impact -argument about the very existence of that world' ${ }^{70}$ The tailors act as if the world they create already exists in order to make the question of commonality the object of dispute. To assume its inexistence would corroborate rather than challenge their bosses' worldview but to dispute its existence assumes that it does exist: an inexistent object would be indisputable. So only by treating the 
legal inscription of the egalitarian community as verifiable with deeds, can the workers demonstrate the unreasonableness of their employers' behaviour and impose a rational obligation on them to listen to their case: 'If Monsieur Persil [the public prosecutor] or Monsieur Schwartz is right to say what he says and what he does, the preamble of the charter must be deleted. If, by contrast, the major premise is upheld, Monsieur Persil and Monsieur Schwartz must speak and act differently'. ${ }^{71}$ The egalitarian inscription gets demonstrated not just by the workers' actions: the bosses and the legal authorities need to behave otherwise if they too include themselves in the community of equals. So while Rancière is criticised for focusing exclusively on the struggles of the oppressed without considering their effects on the police, ${ }^{72}$ the effectiveness of those struggles, he insists, always depends on forcing the police to respond.

The strike illustrates how the inscription of universal equality gets constituted and reshaped through its particular reiterations in diverse situations and settings. It measures the distance between the egalitarian inscription and the workers' experience not to expose 'social equality' as an illusion masking domination but as 'an equality enshrined as a potentiality in legal/political texts, then translated, displaced and maximised in everyday life'. A new daily life could not get established unless politics combines interruption and inscription, unless modes of acting and speaking which acknowledge the equal employer-employee relation become habitual: 'This means making[...] negotiation a customary thing; it also means imposing particular rules of courtesy on the masters or establishing the right to read newspapers in the workshop' ${ }^{73}$ The impact of the radical political events of 1789 and 1830 gets extended beyond these rare insurrectional moments to affect the quotidian as individuals test their inscription of universal equality against their own particular circumstances.

\section{Disrupting to Maintain: The Student Strike of 1986}


De Gouges and the tailors reiterate the Declaration and the Preamble to dispute the existence of worlds yet to exist but already inscribed in the law and their actions. They reconfigure the distribution of public/private, human/citizen, particular/universal. The restaging of events does not, however, only redistribute but also safeguards the distribution of institutions and obligations democratically achieved. As police orders 'give more or less room to democracy', it follows that politics must safeguard that room. ${ }^{74}$ Rancière's examination of the French student strike of 1986 supplies one such case. Whereas de Gouges and the tailors seek to expand the public sphere by including excluded subjects or issues within it, the students seek to defend it against the privatising force of advancing neoliberalism. The neoliberal privatisation of public things, Honig reminds us, erodes the objects of 'contestation' and 'common love' central to democracy. ${ }^{75}$ The iterative dimension of events can resist this process, re-marking them as public, as open to democratic questioning and reconfiguration.

The strike highlights how events, by reiterating the words or actions of earlier events, can forge solidarity with them in order to retrace their struggles and achievements in a context which threatens to diminish or erase them. Recalling the events of May 68, it confirmed how 'collective identification with a free and open university' as 'an inalienable right of French democracy' had survived the decline of revolutionary hope and the triumph of capitalism. ${ }^{76}$ Two hundred thousand students protested against legislation designed to make universities more 'responsive to economic requirements' through 'selective orientation' which aimed to 'match' students' 'abilities with eventual employment.' ${ }^{77}$ Their demonstration succeeded in making the government withdraw its reforms. However, the event's significance lies not exclusively in this outcome. Its spontaneous demonstration of the collective capacity for selfrule exemplifies for others their own capacity to stage a dispute which refuses to let a ruling elite decide how public institutions affect them. ${ }^{78}$ 
The protest, like the previous examples, assumes the status of an event by exposing the universal dimension of the particular conflict of interests that triggered it. It centred on the word 'selection' which reconnected 'the egalitarian signifier' with 'the factual situation of a university open to all regardless of economic considerations' ${ }^{79}$ Students, despite being identified with the logic of selection in terms of choosing the best courses, perceived the distance between the word and the fairly circumspect legislation, taking it to mean 'equality versus inequality', 'the rights of the multitude against the rights of learned administrators'. While this event, as a response to 'some apparently insignificant political measure', arose spontaneously, it still involved coordination and organisation by the students themselves. ${ }^{80}$ They proved their equal capacity with the governing elite, by singlehandedly establishing and running 'national and local committees', by creating 'a strike information network', by circulating and analysing the legislation. ${ }^{81}$ Instead of blindly opposing the law's capitalistic overtones, they pronounced it a 'bad' law. This pronouncement caused governmental 'disarray' for it looked beyond the market as the necessary determinant of public spheres to the possibility of a more democratically oriented police politics. 'Bad legislation' implies the potential for 'good' legislation. The students paradoxically disrupted the status quo by taking 'the politicians seriously', trusting their capacity to make 'laws in the general interests. ${ }^{, 82}$ Interruption occurred, then, not to reject police institutions but to demand that they remain responsive to the identifications, needs, and interests of those people that they occupy them, that they remain democratically shaped.

Like any event, the meanings ascribed to it varied: some welcomed the students' realism which, compared to the vague revolutionary aspirations of their May 68 counterparts, had clear objectives and sense of organisation and others attacked their pettiness and selfinterestedness. These accounts neglected what made this 'modest' strike an event: it 'touched the same sensitive point as the violence of the enragés of May 68', establishing 'a common 
space as a space of division', asserting the 'strength of the dividing many' against 'consensual - and ochlocratic - democratic degeneracy: against government of well selected elites. ${ }^{83}$ Just as the violence of the revolutions had facilitated the workers' equal participation in public debate, the 'victorious calm' of the students' strike 'was only possible thanks to the violence of earlier events which had put the university in question and used the streets to effect communication between a university as a place and a society as a whole' ${ }^{84}$ The strike verified the equality that the events of May 68 had forced into the hierarchical university to dispute the police distribution of the parts and the whole. It re-marked it as a democratic space that seeks 'to include not exclude, to integrate not reject, to encourage not frustrate' 85 , renewing earlier political energies to make this public institution accountable to the public once again.

\section{Conclusion}

Events prepare the ground for future events which repeat, alter and defend their egalitarian inscriptions. They demonstrate to others the power of anyone to interrupt social routines in order to reclaim time and space for politics, to expand the public sphere and defend it against privatisation by governments. 'The permanence of democracy' - as the right to rule of anyone and everyone - lies not in citizens' ritualistic participation in elections or prescribed debates but 'in its mobility, its capacity to shift the sites and forms of participation' so that new areas of social life become marked by democratic action whose trace can always be found again and deepened by more action. ${ }^{86}$ That shifting or reformation requires the constant re-invention of the community of equals, of 'those who have no rights in the matter, but who nonetheless assert such rights' ${ }^{87}$ Olympe de Gouges and the tailors repeat the egalitarian words of the law in order to authorise rights not yet recognised by their societies but which they have proven already exist. By supplementing the law with action they highlight both its force and its limit, they make it accountable for its egalitarian claims and 
bring the authorities to account for their narrow interpretation of it. Likewise, the students enact the right to a free and open university as an inalienable right of French democracy to demonstrate their equality with the ruling elite in deciding public matters. Their repetitions aim to oblige others to alter their sense of what is visible, thinkable, or possible, to sense alternative worlds within the world they have come to accept. By acting as if the equality they perform is already inscribed within police institutions, all three cases make it difficult for the police to reject their demonstrations without contradiction and further dispute. So while subjects may be fleeting, always eventually resuming a place within police distributions, they do not disappear without trace. They have proven to others their capacity for self-rule by writing a public declaration when confined to the private sphere, running their own workshops whilst being simply employed to obey, co-ordinating a national strike to defend a public institution despite being apolitical, self-centred students. Their verification of equality, existing only in act, needs to be constantly reiterated through 'the fresh emergence of' 'subject(s)' who (re)commence, widen or redirect earlier struggles on behalf of worlds yet to exist or in need of maintenance or defence from domination or suppression. ${ }^{88}$ Reiteration involves 'trust' in the egalitarian presupposition. ${ }^{89}$ Trusting does not mean waiting passively for equality to be discerned but making it discernible, enacting it by already living equally in unequal contexts. Rancière's reiteration of events aims to foster that trust by highlighting how "there are moments when the community of equals appears as the ultimate underpinning of the distribution of the institutions and obligations that constitute a society' while also demonstrating how it is constantly challenged. ${ }^{90}$ But those challenges frequently undermine themselves by creating room for further dissensus: the police's attempt to contain events always generates an excess, since the need for containment reaffirms through negation the disruption of the event. The iterability allowing the impact of events to be inscribed socially leaves their inscription unstable. That instability underlines the permanent need for 
their restaging to measure their egalitarian inscription against the police's account of them.

Trusting the collective capacity to rearrange the worlds we share provides the first step

towards re-inventing communities to test the force of equality in places where it is denied or

forgotten. Testing entails not only trust but also 'resolve' to sustain worlds opened but never secured by events, to keep them open by adding new sites, situations and cases to them. ${ }^{91}$

How, when, where events will occur to defend or expand earlier inscriptions of equality remains incalculable but the potential for their occurrence lies not in the depths of society but in its day-to-day functioning.

\footnotetext{
${ }^{1}$ Marina Pretoulis and Lasse Thomassen discuss the 'square' protests and 'occupy' movements of 2011 as enactments of Rancièrian equality to explore their significance for democratic theory in 'Political Theory in the Square: Protest, Representation and Subjectification', CPT, 12:3, 166-184. Chantal Mouffe reviews different theoretical responses to these events in Agonistics (London: Verso 2013), pp. 107-27.

2 Jacques Rancière, The Hatred of Democracy (London: Verso, 2006), 94.

${ }^{3}$ Ellen Myers sees Rancière's politics as hostile to institutions and purely ephemeral in her 'Presupposing equality: The trouble with Rancière's axiomatic approach', $P S C, 40: 8,2014,1-25$. Oliver Marchart criticises his 'overemphasis on the disruptive dimension of politics' and neglect of the 'institutional dimension of democracy' in 'The Second Return of the Political: Democracy and the Syllogism of Equality', in eds. Paul Bowman and Richard Stamp, Reading Rancière (London: Continuum, 2011), 129-147 (135, 141).
}

\footnotetext{
${ }^{4}$ Mouffe, in Agonistics, argues that recent movements such as Occupy cannot overthrow neoliberal hegemony by withdrawing from current institutions; they need to engage with them to make them more representative and accountable (123-27). Her position differs from that of Hardt and Negri for whom the protesters were right to target representative institutions as an obstacle to democracy. See their Declaration (New York: Argo, 2012), pp. 24-35. Rancière argues that we should trust the egalitarian claims of such institutions by verifying them in reality in On the Shores of Politics trans. Liz Heron (London: Verso, 1995), p. 45.

${ }^{5}$ Derrida's idea of the supplement informs my reading. See his Of Grammatology (Baltimore: John Hopkins University Press, 1998), pp. 146-64.

6 Jacques Rancière, Dissensus: on Politics and Aesthetics, ed. and trans. Steven Corcoran (London: Continuum 2010), (57).

${ }^{7}$ Jacques Rancière, Moments politiques: Interventions 1977-2009, trans. Mary Foster (New York: Seven Stories Press, 2014), 197.

${ }^{8}$ Rancière, On the Shores, 90.

${ }^{9}$ Egalitarian iterations can also initiate Events as my interpretation of Ranciere's analysis of the Aventine Secession will show.
} 
${ }^{10}$ The idea of egalitarian iterations recalls Seyla Benhabib's concept of democratic iterations, The Rights of Others: Aliens, Residents and Citizens (Cambridge: Cambridge University Press, 2004), which insists that every iteration of universal rights by particular historical and cultural agents alters the meaning of those rights, the identity of the political community upholding them and the cultural identities of those communities. While iterations, for Rancière and Benhabib, allow the universal to be mediated and questioned by the particular, there are significant differences. First, Benhabib assumes that iterations proceed from an authoritative original. For Rancière, those without authority repeat the original to make unanticipated arguments, highlighting the excess of meaning undermining any authoritative meaning. Second, iterations cause dissensus, for Rancière, rather than consensus. Third, subjects are constituted through and after the iterative act and therefore do not represent pregiven identities but exceed identification. For a critique of Benhabib, see Bonnie Honig, Emergency Politics (Princeton: Princeton University Press, 2009), 112-137 and Thomassen Lasse 'The politics of Iterability: Benhabib, the Hijab, and Democratic Iterations', Polity 43:1, 2011, 128-49.

${ }^{11}$ Rancière, On the Shores, 90.

${ }^{12}$ Ibid.

${ }^{13}$ Ibid., 91.

${ }^{14}$ Ibid., 84

${ }^{15}$ Ibid. The idea of 'constant reiteration' seems contrary to Rancière's assertion of the rarity of politics in his Dis-agreement: Politics and philosophy, trans. Julie Rose (Minneapolis: University of Minnesota Press, 1999) 17. He has revised this view: 'By that, I wanted to say [...] a government and laws are not enough to bring politics into existence. There can be long historical periods without politics. From my point of view, politics is present in all forms of struggle, action, and intervention that reassert decision making over public affairs as anyone's concern, and as the expression of anyone's equal capacity', Moments politiques, 158 (translation modified).

${ }^{16}$ See Derrida Limited Inc. (Evanston Ill: Northwestern University Press, 1988); 'A Certain Impossibility of Saying the Event', Critical Inquiry, 33:2, 2007, 441-61. Aletta Norval uses Derrida's idea of iterability to describe the inscriptive process which, she argues, Rancière's theory neglects in "'Writing a Name in the Sky": Rancière, Cavell, and the Possibility of Egalitarian Inscription', American Political Science Review, 106:4, 2012, 810-826 (820, n.41).

17 Hardt and Negri describe how the movements of 2011 borrowed and adapted slogans and issues from one another to unite 'without contradiction their singular conditions and local battles with the common global struggle', Declaration, 4, 106-7.

${ }^{18}$ The undecidability of repetition and alteration also applies to constative and performative speech acts. The constative never simply repeats facts but also constitutes and reshapes them. Likewise, there is no performative which does not repeat pre-existing norms. For example, the founders of the American Declaration of Independence, Derrida asserts, legitimated their performative act of founding the republic through constative references to the 'Laws of Nature and 'God', 'Declarations of Independence', New Political Science, 7:1, 7-15. ${ }^{19}$ Rancière, The Hatred of Democracy, 94.

${ }^{20}$ For Norval, Rancière's theory privileges interruption over inscription. She uses his historical writings to correct this imbalance. While welcoming her questioning of Rancière as a theorist of pure rupture, I argue that his theory, with its exploration of politics' aesthetic character, already indicates the inseparability of inscription and disruption. See her "'Writing a Name in the Sky"'. See also Slavoj Žižek, The Ticklish Subject: The Absent Centre of Political Ontology (London: Verso 1999), 187-205. While insightfully critical of Žižek's reading, Oliver Davis accepts that Rancière neglects the inscriptive process in his Jacques Rancière (Cambridge: Polity 2010), 92-96.

${ }^{21}$ Rancière, Dis-agreement, 34.

${ }^{22}$ Jacques Rancière, 'Ten Theses on Politics', Dissensus: on Politics and Aesthetics, ed. and trans. Steven

Corcoran (London: Continuum 2010), 27-44, 35.

${ }^{23}$ Rancière, 'Ten Theses', 35.

${ }^{24}$ Rancière, Moments politiques, 138; Chambers discusses political impurity in The Lessons of Rancière, 65-87.

${ }^{25}$ Rancière, 'Ten Theses', 36.

${ }^{26}$ Ibid., 37.

${ }^{27}$ Rancière, Dis-agreement, 27.

${ }^{28}$ Ibid., 34.

${ }^{29}$ Rancière, On the Shores, 84. 
${ }^{30}$ Jacques Rancière, The Ignorant Schoolmaster: Five Lessons in Intellectual Emancipation. trans. Kristin Ross, (Stanford: Stanford University Press 1991), 137-8.

${ }^{31}$ Rancière, On the Shores, p. 50.

32 Ibid., 23-7.

${ }^{33}$ Rancière, Dis-agreement., 33.

${ }^{34}$ Norval, 'Writing a Name in the Sky'; Davis, Jacques Rancière, 94.

${ }^{35}$ Rancière, Dis-agreement, 24.

${ }^{36}$ Ibid., 33.

37 Ibid., 23.

${ }^{38}$ Rancière, Dissensus, 37.

${ }^{39}$ Rancière, Moments Politiques, ix-x.

40 lbid., ix.

${ }^{41}$ Rancière, Dis-agreement, 22-23.

${ }^{42}$ Rancière, On the Shores, 65.

${ }^{43}$ Chambers, The Lessons of Rancière, 87.

${ }^{44}$ Rancière, Dis-agreement, 31.

${ }^{45}$ Rancière, Moments Politiques, 144.

${ }^{46}$ Rancière, On the Shores, 87.

${ }^{47}$ Rancière, Dissensus, 69.

48 Joan Wallach Scott, 'French Feminists and the Rights of 'Man': Olympe de Gouges' Declarations', History Workshop Journal, 28:1 (1989), 1-21 (7).

49 De Gouges cited in Rancière, The Hatred of Democracy (London: Verso, 2006), 60.

50 Joshua Rivas, 'The Radical Novelty of Olympe de Gouges', Nottingham French Studies, 53:3 (2014), 345-358 (351).

${ }^{51}$ Scott, 'French Feminists', 16-17.

${ }^{52}$ Rancière, Dissensus, 62.

${ }^{53}$ Scott, 'French feminists', 17.

${ }^{54}$ Rancière, Dissensus, 68.

${ }^{55}$ Ibid., 23.

${ }^{56}$ Rancière, On the Shores, 49.

57 'Politics, Identification, Subjectivation', 60.

${ }^{58}$ Norval, "Writing a Name in the Sky", 817.

${ }^{59}$ Rancière, 'Politics, Identification and Subjectivization', 61.

${ }^{60}$ Ibid.

${ }^{61}$ Ibid., 72.

62 Ibid.

${ }^{63}$ Rancière, On the Shores, 51.

${ }^{64}$ Rancière, 'Politics, Identification and Subjectivization', 62.

${ }^{65}$ Rancière, On the Shores, 68.

${ }^{66}$ Rancière, Dis-agreement, 52.

${ }^{67}$ Rancière, On the Shores, 48.

68 Ibid., 49.

${ }^{69}$ William Sewell also shows how workers exploited revolutionary rhetoric to endow themselves 'with the power of public speech ...the power to redefine the moral and social world'. See his Work and Revolution in France (Cambridge: CUP, 1980), p. 201.

${ }^{70}$ Dis-agreement, 56.

${ }^{71}$ Rancière, On the Shores , 47.

${ }^{72}$ See n32.

${ }^{73}$ Rancière, On Shores of Politics, 48.

${ }^{74}$ Rancière, The Hatred of Democracy, 72.

75 Bonnie Honig, 'The Politics of Public Things: Neoliberalism and Routine Privatisation', NoFo, 10 (2013), 59-76 (60).

${ }^{76}$ Rancière, On the Shores of Politics, 56. For a discussion of May 68 inspired by Rancière's thought, see Kristin Ross, May 68 and its Afterlives (Chicago: Chicago University Press, 2002).

77 On the Shores of Politics, 55

78 The student movement, Bryson asserts, inspired the strikes of transport workers occurring shortly afterwards. Both strikes demonstrated the existence of a popular base 'at once educated, informed and 
articulate'. Scott Bryson, 'France Through the Looking Glass : The November-December 1986 French Student Movement', The French Review, 61:2, 1987, 247-260 (257).

${ }^{79}$ Rancière, On the Shores, 91.

${ }^{80}$ Jodi Dean reproaches Rancière for rejecting organised resistance in her 'Politics without politics' in Reading Rancière, 73-94. For a reply to Dean, see Claire Woodford, 'Reinventing modes of dreaming' and doing: Jacques Rancière and strategies for a new left', $P S C, 41: 8,811-836$. Rancière refutes any simple opposition between spontaneity and organisation, Moments politiques, 159, 192.

${ }^{81}$ Bryson, 'France Through the Looking Glass', 256.

${ }^{82}$ Rancière, On the Shores, 56, 57.

${ }^{83}$ Ibid., 58.

${ }^{84}$ Ibid., 91.

${ }^{85}$ Bryson, 'France Through the Looking Glass', 254.

${ }^{86}$ Rancière, On the Shores, 60.

${ }^{87}$ Ibid., 91.

${ }^{88}$ Ibid., 61.

${ }^{89}$ Ibid

90 Ibid., 91.

${ }^{91}$ Ibid., 91. 